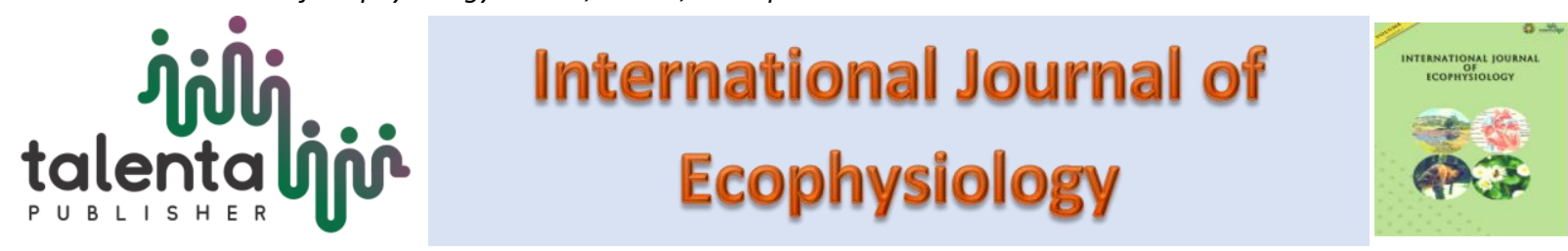

\title{
Arboretum as Carbon Stock and Carbon dioxide Uptake to Support the Realization of Green Campus at Riau University
}

\author{
Sri Wulandari ${ }^{1 *}$, Suwondo $^{2}$, Firdaus $^{3}$, Nursal $^{4)}$ \\ Study Program of Biology Education, Faculty of Teacher Training and Education, Universitas Riau, \\ Pekanbaru 28131, Indonesia
}

\begin{abstract}
The University of Riau Arboretum is one of the natural environments contained within the campus, having various types of vegetation that can be utilized to support the realization of a green campus. This study aims to determine the benefits of arboretum as carbon reserves and $\mathrm{CO}_{2}$ uptake to support the realization of Riau University's green campus. Research using survey methods by observing in the arboretum. Determination of sampling locations by purposive random sampling by considering the condition of vegetation and topography. Research parameters are: (1) vegetation analysis; (2) carbon stocks and (3) $\mathrm{CO}_{2}$ uptake. The University of Riau Arboretum has a vegetation composition in all strata, namely seedlings, saplings, poles and trees. The number of individual seedlings is higher than other strata, namely 349 individuals. Diversity index in all strata classified as high criteria ranged from 3.22 to 3.42 . The total carbon stock of 1.12 tons / ha and $\mathrm{CO}_{2}$ absorption of 4.11 tons / ha, with the arboretum of Riau University ( $\pm 10 \mathrm{ha}$ ), the $\mathrm{CO}_{2}$ absorption that occurs is 41.1 tons. Thus the existence of arboretum can be used to further optimize its function as carbon reserves and $\mathrm{CO}_{2}$ absorption in realizing the green campus program of the University of Riau.
\end{abstract}

Keyword: Arboretum, carbon stock, $\mathrm{CO}_{2}$ uptake

Received 15 November 2019 | Revised 29 December2019| Accepted 29 January2020

\section{Introduction}

The University of Riau's Binawidya campus has a large area with interesting topographical and landscape conditions. The Tri Dharma of Higher Education is expected to be able to support government policy by implementing sustainable development. Campus activities are carried out by integrating the environmental (ecological), economic and socio-cultural components of the community in Riau Province. To achieve this we need a green campus management strategy.

The Green Campus Program aims to make the campus environment a comfortable, clean, green, beautiful and healthy place. Understanding green campus in the context of environmental

\footnotetext{
*Corresponding author at: Study Program of Biology Education, Faculty of Teacher Training and Education, Universitas Riau, Pekanbaru 28131, Indonesia

E-mail address: wulandari_sri67@yahoo.co.id
} 
preservation is not just a campus environment filled with green plants, but a deeper meaning that is the extent to which campus residents can utilize existing resources within the campus environment effectively and efficiently.

Environmental problems are joint problems that require synergy of all elements of society, including the academic community. The academic community has great potential in building integrated, comprehensive and sustainable environmental management, because it is necessary to develop a concept that can unite all elements in an environmental management system.

One of the resources available at the University of Riau is the arboretum. The term arboretum describes a Green Open Space (RTH) which is planted with various types of vegetation which have the main function as an integrated educational facility with various other important roles. The existence of the arboretum is very important in realizing the green campus program.

The University of Riau Arboretum has an area of \pm 10 ha that has experienced succession and is used as a place to facilitate the learning process, practicum and research. Based on observations is one type of lowland forest that is quite good and has a variety of flora, but so far no research has been conducted to obtain information on the carbon stock content stored in living plants in the area. The presence of arboretum with the vegetation in it is expected to increase oxygen production and filter out polluted particles in the air thereby increasing environmental quality. The structure of forest vegetation in tree strata has the ability to absorb pollutant gases such as $\mathrm{CO}_{2}$. Forests have different tree species compositions and with different carbon absorption abilities. According to Hairiah and Rahayu [1], the potential for carbon sequestration by ecosystems depends on the type and condition of the ecosystem, namely the composition of the type and structure of the vegetation. Composition and structure shows the types of plants found in a vegetation and the level of stratification in a vegetation which is also related to the level of diversity, density, frequency, dominance and importance.

Carbon reserves are carbon content stored in living plants (biomass), dead plants (necromass), and carbon stocks in the soil. Information on carbon stocks in living plants is needed as a consideration in efforts to preserve vegetation in the arboretum area of Riau University.

Plants need sunlight, carbon dioxide which is absorbed from the air and water and nutrients that are absorbed from the soil for survival. Through the process of photosynthesis, $\mathrm{CO}_{2}$ in the air is absorbed by plants and converted into carbohydrates, then spread throughout the body of the plant and finally piled up in the body of plants in the form of leaves, stems, twigs, flowers and fruit. The process of accumulation of $\mathrm{C}$ in the body of living plants is called the sequestration process (C-sequestration). Thus, measuring the amount of $\mathrm{C}$ stored in the body of living plants (biomass) in a field can describe the amount of $\mathrm{CO}_{2}$ in the atmosphere absorbed by plants [1]. 
Absorption of $\mathrm{CO}_{2}$ in large quantities can reduce $\mathrm{CO}_{2}$ emissions causing air pollution in the atmosphere.

In addition to acting as a carbon storage store, arboretum is one of the Green Open Space (RTH) that produces oxygen and can indirectly reduce air pollution at the University of Riau. According to Simpson and McPherson [2], the absorption of carbon dioxide by green open space with 10,000 trees aged 16-20 years can reduce carbon dioxide by 800 tons / year. Planting trees results in the absorption of carbon dioxide from the air which is then stored as carbon reserves in the form of biomass until the carbon is released again because the vegetation is rotten or burned. IPPC [3] states that this is due to the green space that is managed and planted will cause carbon sequestration from the atmosphere, then a small portion of the biomass is harvested and / or logged in a ripe or decayed condition. Therefore, the presence of arboretum is important for the University of Riau to maintain the beauty of the environment and create conditions conducive to the learning process on campus. Based on these problems, it is necessary to conduct research on "Arboretum as Carbon Reserves and $\mathrm{CO}_{2}$ Uptake in Creating Green Campus of Riau University".

\section{Materials and Methods}

This research was conducted at the University of Riau Arboretum with a purposive random sampling method by considering the condition of vegetation, environment, and topography. The tools and materials used in this study were digital camera, stationery, rope, fabric meter, wood (1.3 meter), tally counter and clinometer. The parameters used include analysis of tree vegetation, estimation of tree biomass, and carbon stocks.

This research is a descriptive research with survey method, field data collection using the plot method. Data were analyzed quantitatively according to Mueller-Dombois and Ellenberg [4] to determine vegetation composition and diversity index. Furthermore, the data are analyzed to determine the estimation of carbon stocks by first calculating tree biomass using the allometric equation [5], [6] as follows:

$$
\begin{aligned}
& \mathrm{Y}=0,0509 \times \rho \times \mathrm{DBH} 2 \times \mathrm{T} \\
& \mathrm{Y}=\text { total biomass }(\mathrm{kg}) \\
& \rho=\text { wood specific gravity }(\mathrm{g} / \mathrm{cm} 3=0.68 \mathrm{gr} / \mathrm{cm} 3) \\
& \mathrm{DBH}=\text { diameter at breast height }(\mathrm{m}) \\
& \mathrm{T}=\text { plant height }(\mathrm{m})
\end{aligned}
$$

If all stand biomass data obtained on a land is added up then total biomass per land $(\mathrm{kg} / \mathrm{land}$ area) will be obtained, which can then be calculated biomass per hectare using the formula as in the following equation: 


$$
\begin{aligned}
& \mathbf{W}=\frac{\sum_{\mathrm{i}=1}^{\mathrm{n}} \mathbf{W p i}}{\mathbf{A}} \times \mathbf{1 0 . 0 0 0} \\
& \mathrm{W}=\text { total tree biomass (ton } / \text { ha) } \\
& \mathrm{n}=\text { number of trees } \\
& \mathrm{W} \mathrm{pi}=\text { tree biomass (tons) } \\
& \mathrm{A}=\text { area }(\mathrm{m} 2)
\end{aligned}
$$

Carbon stock (C-stock) is calculated using the approach of biomass, carbon dioxide absorbed by plants through the process of photosynthesis stored in the form of biomass. The carbon stock stored in the form of biomass can be determined by multiplying the biomass by the carbon fraction of the biomass, which is generally 0.50 [3], [7].

$$
\begin{aligned}
& \mathrm{C}=\mathrm{W} \times 0,5 \\
& \mathrm{C}=\text { Saved carbon stock (tons } / \mathrm{ha}) \\
& \mathrm{W}=\text { Biomass }(\text { ton } / \mathrm{ha}) \\
& 0.5=\text { Proportion of carbon }
\end{aligned}
$$

Calculation of $\mathrm{CO}_{2}$ uptake can be done using the results of carbon stock calculations (C-stock). The formula for calculating $\mathrm{CO}_{2}$ absorption according to IPCC [8] is as follows.

$$
\begin{aligned}
& \mathrm{EC}=3,67 \times \mathrm{C} \\
& \mathrm{EC}: \mathrm{CO}_{2} \text { uptake (tons of } \mathrm{CO}_{2} / \mathrm{ha} \text { ) }
\end{aligned}
$$

3.67: Relative molecular value (MR) of $\mathrm{CO}_{2}$ to carbon: $44 / 12$ (tons $\mathrm{CO}_{2} /$ ton $\mathrm{C}$ )

C: Stored carbon reserves (tons $\mathrm{C} / \mathrm{ha}$ )

\section{Result and Discussion}

Based on research that has been carried out in the arboretum area of Riau University campus, it is found the composition of families, types and number of individuals in each stratum, which can be seen in Table 1 below.

Table 1. Composition of vegetation in Riau University arboretum

\begin{tabular}{cccc}
\hline Growth level & Family & Species & Individu \\
\hline Seedling & 20 & 30 & 349 \\
Stake & 19 & 32 & 312 \\
Pole & 21 & 33 & 229 \\
Tree & 20 & 35 & 146 \\
\hline
\end{tabular}

In Table 1 above, it can be seen that the number of individuals in the seedling strata is higher than in other strata. This is because seedlings are the first stage during the succession process in an area. Generally seedlings are found in open areas on the canopy cover due to fallen or dead trees and there are many at the edge of the open arboretum area. Types of seedlings that dominate are pioneer plants such as mahang (Macaranga sp.), elephant footprint (Ipomea sp.), pelangas (Aporosa aurita) and Laban (Vitex pinata). Trees have the fewest number of individuals because not all types of ponons are able to adapt to grow until they reach the tree strata. Moraceae family has the most number (7 types) consisting of tempunik (Artocarpus rignus), terapis (Artocarpus elasticus), breadfruit (Artocarpus altilis), pudu (Artocarpus 
command), semantung (Ficus grossularioides), tempinis (Artocarpus elasticus), breadfruit (Artocarpus altilis), pudu (Artocarpus command), semantung (Ficus grossularioides), tempinis (Artocarpus elasticus), breadfruit (Artocarpus altilis), pudu (Artocarpus command) (Artocarpus integer).

Diversity index shows the number of species among the total number of individuals who are in the location. The diversity of seedling, sapling, pole and tree levels in the arboretum area of Riau University in Table 2 as follows.

Tabel 2. Index of diversity of vegetation in the University of Riau arboretum

\begin{tabular}{ccc}
\hline Growth level & Diversity index $\left(\mathrm{H}^{\prime}\right)$ & criteria \\
\hline Seedling & 3.22 & high \\
Stake & 3.31 & high \\
Pole & 3.42 & high \\
Tree & 3.35 & high \\
\hline
\end{tabular}

Based on Table 2, it can be seen that the diversity index of seedlings, saplings, poles and trees has a range that is not too much different, namely between 3.22-3.42 with a high category. According to Shannon Wienner [9], if the diversity index value is less than 1, it means that species diversity is low, if between 1-3 means moderate species diversity, if greater than 3 means high species diversity. Pole species diversity is higher than other strata, this condition will affect the level of diversity of stakes and seedlings, because the stratum strata that have a tight canopy so that species that cannot stand with low light intensity are unable to survive.

Carbon reserves are determined by calculation of tree biomass. Carbon stock represents $50 \%$ of the calculated tree biomass. Whereas $\mathrm{CO}_{2}$ absorption is determined by calculations using carbon stock data. The results of the calculation of biomass, carbon stocks and $\mathrm{CO}_{2}$ uptake in tree strata at each of the University of Riau arboretum locations can be seen in Table 3.

Table 3. Total biomass, carbon stock and $\mathrm{CO}_{2}$ uptake in tree strata at the Universitas Riau arboretum

\begin{tabular}{|c|c|c|c|c|}
\hline No & Location & $\begin{array}{c}\text { Biomass } \\
\text { (ton/ha) }\end{array}$ & $\begin{array}{c}\text { Carbon reserve } \\
\text { (ton/ha) }\end{array}$ & $\begin{array}{l}\text { Absorbed } \mathrm{CO}_{2} \\
\text { (ton/ha) }\end{array}$ \\
\hline 1 & $\begin{array}{ll}\text { Northern } & \text { reservoir } \\
\text { Fishery Faculty } & \end{array}$ & 0.79 & 0.40 & 1.47 \\
\hline 2 & $\begin{array}{l}\text { Nortern part of kupu-kupu } \\
\text { bridge }\end{array}$ & 0.67 & 0.33 & 1.21 \\
\hline 3 & $\begin{array}{l}\text { Western part mini } \\
\text { stadium Riau University }\end{array}$ & 0.77 & 0.39 & 1.43 \\
\hline & TOTAL & 2.23 & 1.12 & 4.11 \\
\hline
\end{tabular}

In Table 3, overall the total biomass in the University of Riau Arboretum is 2.23 tons / ha, carbon stocks are 1.12 tons / ha and $\mathrm{CO}_{2}$ absorption is 4.11 tons / ha. The overall area of the University of Riau Arboretum is \pm 10 ha, so that the estimated total $\mathrm{CO}_{2}$ absorption is 41.1 tons. 
The highest $\mathrm{CO}_{2}$ uptake is in the northern part of the Faculty of Fisheries reservoir, which is 1.47 tons / ha.

The amount of $\mathrm{CO}_{2}$ uptake found at that location is caused by the high carbon stock and the density of trees found at that location. At the western location of the mini stadium of the University of Riau, although the level of vegetation density is low compared to other locations, the trees found in that location have a relatively large diameter, so that carbon stocks and $\mathrm{CO}_{2}$ uptake are in the second position of 0.39 tons / ha and 1.43 tons / ha. This shows that one of the causes of differences in the amount of carbon stock and $\mathrm{CO}_{2}$ uptake at each study site is due to differences in plant density at each location. According to Rahayu [10], carbon stocks in a land use system are influenced by the type of vegetation. A land use system that consists of trees with species that have a high value of wood density, the biomass will be higher when compared to land that has species with low wood density values. Purwanto's research results [11] showed that the criteria for carbon stock or (stock) carbon in a forest ecosystem can be divided into 3, namely low carbon stock ( $<35$ tons / ha), medium carbon stock (35-100 tons/ha), and high carbon stock (>100 tons / ha). Carbon stock or carbon stock contained in the University of Riau Arboretum based on the results of the study has a value of 11.2 tons and is included in the low category.

Arboretum has great potential as a carbon sink and $\mathrm{CO}_{2}$ absorber. Forest sustainability will be maintained naturally because it has high species diversity and is dominated by small diameter trees $(<20 \mathrm{~cm})$. These small diameter trees will make a major contribution to increasing carbon stocks and $\mathrm{CO}_{2}$ absorption in the future. Increasing carbon stocks and sequestering $\mathrm{CO}_{2}$ can be done through the addition of tree reserves in existing forests. Tree planting and maintenance activities are the easiest way to increase carbon and $\mathrm{CO}_{2}$ reserves because trees are able to absorb carbon and store it as biomass in the trunk. A good management of the University of Riau Arboretum will have the potential to increase the ability of vegetation to absorb and store carbon that is useful to support the green campus program. 


\section{Conclusion}

The University of Riau Arboretum has a vegetation composition in all strata, namely seedlings, saplings, poles and trees. The number of individual seedlings is higher than other strata, namely 349 individuals. Diversity index in all strata classified as high criteria ranged from 3.22 to 3.42. The total estimated $\mathrm{CO}_{2}$ uptake in Riau University arboretum is 4.11 tons / ha, with the University of Riau aboretum area ( \pm 10 ha), the $\mathrm{CO}_{2}$ absorption that occurs is 41.1 tons, thus the presence of arboretum can be used to further optimize its function as carbon stocks and $\mathrm{CO}_{2}$ absorption in realizing the green campus program at the University of Riau.

\section{REFERENCES}

[1] Hairiah, K., Rahayu, S. Pengukuran Karbon Tersimpan. Di Berbagai Macam Penggunaan Lahan. World Agroforestry Centre. Bogor. 2007.

[2] Simpson, J.R dan McPherson. Carbon Dioxide Reduction Through Urban ForestyGuidelines for Professional and Volunter Tree Planters. Gen. Tech. Rep. PSW-GTR-171. Albany, CA: Pacific Southwest Research Station, Forest Service, U.S. Departmen of Agriculture. 1999.

[3] Intergovernmental Panel in Climate Change (IPPC). Greenhouse gas inventory reference manual. IPCC WGI Technical Support Unit, Hardley Center, Meteorology Office, London Road, Braknell, RG 122 NY, United Kingdom. 1995.

[4] Mueller-Dombois, dan Ellenberg. Aims and Methods of Vegetation Ecology. John Wiley \& Sons. New York. 1974.

[5] Maurin P, Rahmawaty, Riswan. Pendugaan Cadangan Karbon Above Ground Biomass (AGB) pada Tegakan Hutan Alam di Kabupaten Langkat. Jurnal kehutanan 1(3) : 99-105. Fakultas Pertanian Universitas Sumatera Utara. Medan. 2012.

[6] Handi Supriadi. Peran tanaman karet dalam mitigasi perubahan iklim. Jurnal buletin RISTRI 3(1) : 79-90. Balai Penelitian Tanaman Industri dan Penyegar. Bandung. 2012.

[7] Ari, W. Menghitung Cadangan Karbon dan Emisi Gas Rumah Kaca Sektor Kehutanan. Pusat Litbang Perubahan Iklim dan Kebijakan Yogyakarta. 2013.

[8] Intergovernmental Panel in Climate Change. IPCC Guidelines for National Greenhouse Gas Inventories. 2006.

[9] Odum, E.P. Dasar-Dasar Ekologi. Terjemahan T. Samingan. Gadjah Mada University Press. Yogyakarta. 1996.

[10] Rahayu, S., Lusiana, B, dan Van Noordwijk, M. Pendugaan Cadangan Carbon di Atas Permukaan Tanah pada Berbagai Sistem Penggunaan lahan di Kabupaten Nunukan, Kalimantan Timur. World Agroforestry Centre. Bogor. 2007.

[11] Purwanto, R.H. Materi Kuliah Inventaris Biomassa Hutan. Fakultas Kehutanan Universitas Gadjah Mada. Yogyakarta. 2012. 